\title{
Endovascular treatment of occlusive central venous disease: one center's experience
}

\section{Tratamento endovascular da doença venosa oclusiva central: experiência de um centro}

José Manoel da Silva Silvestre', Fernando Barbosa Trevisan', Wander Eduardo Sardinha', Domingos Moraes Filho', Eduardo Durante Ramires', Silfayner Victor Mathias Dias' ${ }^{1}$ Henrique Matsuda

\begin{abstract}
Introduction: The majority of cases of stenosis or occlusion of central veins are the result of central catheters, arteriovenous fistulas, neoplasms or traumas and these conditions can cause severe cases of venous hypertension or reduce the flow through fistulas. The objective of this study is to analyze the results of central venous angioplasties conducted at our hospital. Methodology: We conducted a retrospective and descriptive study to analyze the results of central venous angioplasties conducted from 2010 to 2012 at a university hospital run by the Universidade Estadual de Londrina, Brazil. We calculated primary and secondary success rates and analyzed whether or not stents were used and complications occurred during a 6-month follow-up period. Results: A total of 25 central venous angioplasties were conducted. Twenty-four (96\%) of these were because of catheter-related intimal hyperplasia and one was to treat the effects of compression by a tumor. Fifteen (60\%) angioplasties were to correct stenosis and ten (40\%) were because of occlusions, with a one-hundred percent success rate for all stenosis-related procedures. However, none of the cases of occlusion could be treated endovascularly. Patency during the 6-months follow-up period was $80 \%$ after reinterventions. Conclusions: Despite good results observed after primary interventions for stenoses, it must be accepted that all current treatment options for chronic occlusive venous disease will, sooner or later, lead to restenosis or occlusion. Venous occlusions constitute a challenge demanding the development of new techniques and new materials. Prevention is paramount, through avoidance of central catheterization and early creation of arteriovenous fistulas.
\end{abstract}

Keywords: angioplasty; stenosis venous; venous hypertension.

\begin{abstract}
Resumo
Introdução: A estenose ou a oclusão de veias centrais ocorre, na maioria das vezes, em consequência de catéteres centrais, fístulas arteriovenosas, neoplasias e traumas, podendo levar a quadros severos de hipertensão venosa e de redução do débito dessas fístulas. O presente trabalho tem como objetivo analisar os resultados obtidos nas angioplastias venosas centrais em nosso hospital. Metodologia: Realizamos um estudo retrospectivo, descritivo, analisando os resultados obtidos nas angioplastias venosas centrais realizadas no Hospital Universitário da Universidade Estadual de Londrina durante os anos de 2010 a 2012. Verificamos as taxas de sucesso primário e secundário, a utilização ou não de stents e as complicações, analisadas durante um período de acompanhamento de seis meses. Resultados: Foram realizadas 25 angioplastias venosas centrais, sendo 24 (96\%) por hiperplasia intimal relacionada ao uso de catéteres e uma por compressão tumoral. Destas, 15 (60\%) eram estenoses e dez (40\%) eram oclusões, obtendo-se sucesso primário técnico em todos os procedimentos relacionados à estenose. Contudo, nenhum caso de oclusão pode ser tratado por via endovascular. No acompanhamento de seis meses, após reintervenções, observamos perviedade de 80\%. Conclusão: Apesar dos bons resultados observados nas intervenções primárias sobre as estenoses, indiscutivelmente todas as opções atuais para o tratamento da doença venosa oclusiva crônica irão levar, precoce ou tardiamente, à reestenose ou à oclusão. As oclusões venosas constituem uma incitação para o desenvolvimento de novas técnicas e novos materiais. A prevenção assume papel preponderante, com redução da implantação de catéteres centrais e da realização precoce de fístulas arteriovenosas.
\end{abstract}

Palavras-chave: angioplastia; estenose venosa; hipertensão venosa.

\footnotetext{
'Universidade Estadual de Londrina - UEL, Departamento de Clínica Cirúrgica, Londrina, PR, Brazil. Financial support: None.

Conflicts of interest: No conflicts of interest declared concerning the publication of this article.

Submitted: 11.22.13. Accepted: 01.17.14.
} 


\section{INTRODUCTION}

Central occlusive venous disease (COVD) can be defined as the occlusion or reduction of at least $50 \%$ of the lumen of the internal jugular, subclavian, axillary, innominate or superior cava veins. In the majority of cases this disease is the result of trauma, neoplasm, central catheters or high flow arteriovenous fistulas, the last two of which are the most common causes; it is primarily triggered by development of intimal hyperplasia in up to $40 \%$ of terminal kidney disease patients. ${ }^{1}$

The disease has great clinical importance, not only because of the appearance of the debilitating signs and symptoms of chronic venous hypertension (Figure 1), but also because of the risk of losing venous access in hemodialysis patients.

Since their development, endovascular interventions have become the treatment of choice. Options include percutaneous angioplasties, with or without the use of stents. The objective of this study is to report on our experience with endovascular treatment of central occlusive venous disease, describing indications, primary and secondary success rates, complications and 6-month followup results.

\section{PATIENTS AND METHODS}

A total of 25 central venous angioplasties were performed between January 2010 and December 2012. Thirteen $(52 \%)$ of the patients were male and the mean age of the sample was 52 years. There were twenty-four chronic hemodialysis patients who had central vein disease caused by previous catheterizations and just one patient who had angioplasty for treatment of superior vena cava syndrome caused by constriction by a tumor (breast cancer metastases).

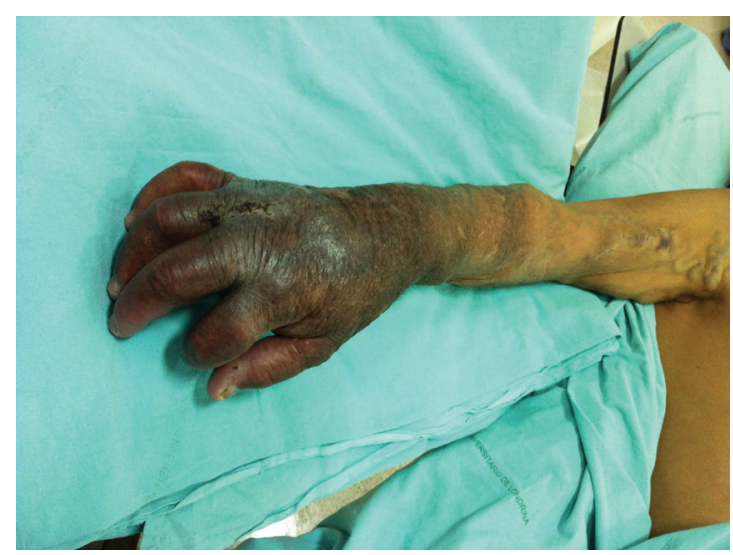

Figure 1. Right upper limb with signs of severe chronic venous hypertension.
We conducted a retrospective and descriptive study based on review of patient records, test results and images of the procedures performed during this period at the university hospital run by the Universidade Estadual de Londrina, Brazil. The criteria for considering a case to be a clinical success were significant improvement in the signs and symptoms of chronic venous hypertension and in flow through the arteriovenous fistula. However, arm circumference measurements were not taken during that period. Recurrence of the symptoms was considered clinical failure, as were attempts to conduct additional angioplasty, whether successful or not.

\section{Procedure}

Peripheral and central phlebographies were obtained for diagnostic assessment and treatment planning via puncture of a peripheral vein or an arteriovenous fistula in the limb with venous hypertension. After confirmation of stenosis or occlusion, a $6 \mathrm{~F}$ sheath was fitted and a hydrophilic guidewire supported by a catheter was advanced in an attempt to cross the lesion. After anticoagulation with 5000 UI of intravenous unfractionated heparin and placement of the guidewire, in cases in which the attempt to cross the lesion was successful, a highpressure balloon was positioned and expanded. Two control phlebographs were taken, one immediately and the other 15 minutes after angioplasty; if there was greater than $30 \%$ residual stenosis, a second angioplasty was performed, using a cutting balloon and/or self-expanding stent (Figure 2). All patients were discharged on the day of the procedure, after some hours of observation, and none were given anticoagulants or platelet antiaggregants during the postoperative period.

\section{RESULTS}

The angioplasty was a primary intervention in $21(84 \%)$ out of 25 cases, while four $(16 \%)$ procedures were to treat restenoses that had occurred after previous angioplasties. Fifteen $(60 \%)$ cases were stenosis and the other ten $(40 \%)$ were occlusions. The innominate vein was the most common topography, involved in $17(68 \%)$ cases, followed by the subclavian vein, with five (20\%) cases, and the superior vena cava, affected in three $(12 \%)$ cases (Table 1).

With relation to the subset of primary angioplasties, $11(52.3 \%)$ were stenoses and ten $(47.7 \%)$ were occlusions. The attempt to cross the lesion was unsuccessful in all cases of occlusion and none of them could be recanalized. In these cases either 


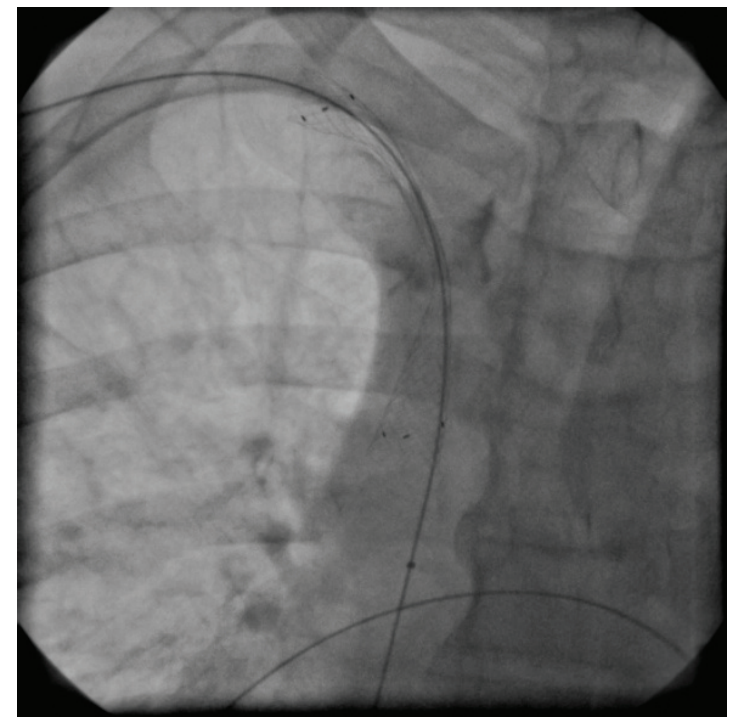

Figure 2. Fluoroscopy showing release of self-expanding stent and a residual lesion after balloon angioplasty.

Table 1. Demographic data and risk factors.

\begin{tabular}{lc}
\hline & Angioplasties \\
\hline Patients & 25 \\
Age (years) & $52 \pm 16$ \\
Sex: male / female & $52 \% / 48 \%$ \\
Hypertension & $70 \%$ \\
Diabetes & $50 \%$ \\
Smoking & $25 \%$ \\
Etiology: intimal hyperplasia & $24(96 \%)$ \\
Stenosis / occlusions & $15(60 \%) / 10(40 \%)$ \\
Secondary angioplasties & $4(25 \%)$ \\
Use of stent & $7(47 \%)$ \\
Follow-up (months) & $5 \pm 5$ \\
\hline
\end{tabular}

clinical observation or ligature of the fistula was chosen. In contrast, treatment proved possible in all $(100 \%)$ of the stenosis cases. In five $(45.4 \%)$ cases the balloon alone was sufficient to achieve good results; self-expanding stents were used in the other six (54.5\%): five for residual stenosis (Figure 2) or remodeling, and, in the patient who had stenosis due to compression by a tumor, a covered stent was used because of a rupture of the innominate vein (Figure 3).

At a 30-day assessment, all 11 of the patients who had been treated were asymptomatic. Nine of these 11 patients returned for follow-up. Of these nine patients, two (22.2\%) angioplasties had become obstructed by 6 months, one that had been treated using a stent and one that had not, and in neither case recanalization was possible. None of the remaining seven patent angioplasties required further intervention during the period analyzed.

With regard to the subset of four secondary angioplasties, all procedures were successful. Two were cases of restenosis after angioplasty of the innominate vein in which a stent had not been used and the other two were restenoses, one of the subclavian vein and the other of the innominate vein, after angioplasty in which a stent had been used. Only one of these four repeat angioplasties required a new stent and this was also the only case that occluded during follow-up, within 3 months.

\section{DISCUSSION}

The incidence of COVD is growing because of its frequent etiologic association with ever more common use of central venous catheters
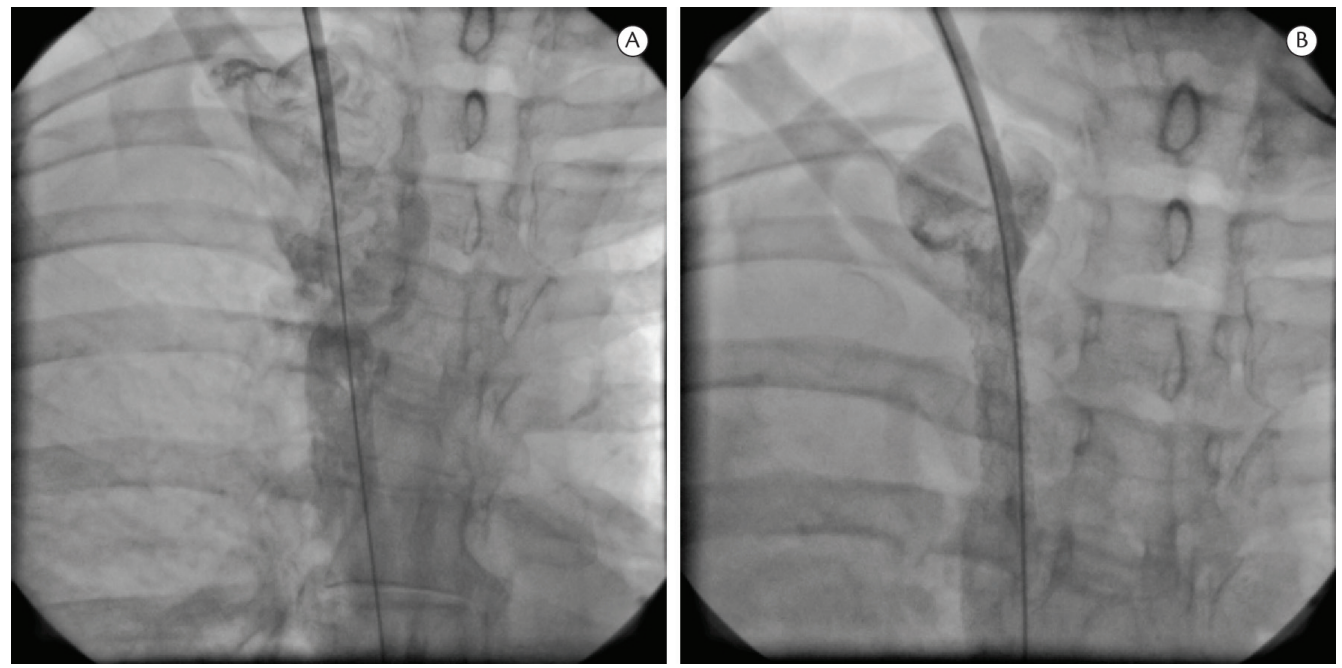

Figure 3. Phlebography showing rupture of the superior vena cava: A, before correction, with leakage of contrast. B, after correction with a covered stent. 
and cardiac pacemaker wires..$^{2-4}$ One study found that $27 \%$ of patients with COVD had a previous history of catheters or pacemaker wires, ${ }^{2}$ primarily in subclavian veins, in which the occurrence of the disease can reach $50 \%$, in contrast with the internal jugular vein, in which the occurrence rate is $10 \%{ }^{3}$ This prevalence was associated with the large caliber of hemodialysis catheters and the high flow rates of dialysis sessions. The potential mechanism of COVD development caused by venous catheter placement can be explained by the trauma to endothelium caused by the catheter and the consequent inflammatory damage to the wall of the vessel, particularly when introduced via the subclavian vein, which is longer, has a tortuous course and is lodged against the first rib. ${ }^{3,5-8}$ Other than catheters, another common cause of this type of injury in central veins is the turbulent venous flow of high output arteriovenous fistulas, which also cause endothelial injury followed by an inflammatory process. ${ }^{1,9}$

Central occlusive venous disease can be symptomatic or asymptomatic. Symptoms can very depending on progression and the anatomic position of the disease. ${ }^{2,9}$ Stenosis and occlusions in subclavian veins can cause venous hypertension in upper limbs, characterized by edema, cyanosis, varicose veins, hyperpigmentation and even ulcers (Figure 1). In more central sites, such as the brachiocephalic vein, they can also cause edema of face and chest and induce development of the superficial venous network in this area. ${ }^{9-11}$ In patients on hemodialysis, output may be reduced and venous pressure increased, leading to inefficient dialysis. Patients who have venous compression by tumors will also present the signs and symptoms of their underlying disease, combined with those of venous hypertension just described.

Diagnostic suspicion is raised by clinical status. However, diagnostic confirmation can only be achieved through supplementary imaging exams. A venous ultrasonography study may show waves without cardiac and respiratory phasicity, which is a finding with a high positive predictive value.9,12 Venous phlebography with digital subtraction is still considered the gold standard. ${ }^{13}$ However, angiotomography and magnetic resonance angiography could be alternatives to conventional angiography, although it should be stressed that patients with slower glomerular filtration rates are at risk of developing nephrogenic systemic fibrosis, caused by the gadolinium used in magnetic resonance angiography. ${ }^{14}$

Currently, the treatment of choice is endovascular, which can be conducted with or without stents. Rates of immediate technical success of angioplasties conducted with a balloon alone can vary from 70 to $90 \% \cdot{ }^{1,15-20}$ In a study conducted by Kovalik et al. ${ }^{16}$ in 1994, the authors observed that there were two types of central venous injuries: non-elastic lesions, which respond well to angioplasty, and elastic lesions, which do or do not respond to angioplasty. Therefore, elastic lesions tend to maintain less patency in relation to non-elastic lesions.

The long-term patency outcomes of angioplasties for COVD using only a balloon have a wide range of variability. There are reports of primary patency at 6 months, varying from 23 to $55 \% .^{1,15-20}$ In 2007, in one of the largest studies of angioplasties for COVD undertaken to date, Bakken et al. ${ }^{20}$ studied 47 patients and demonstrated a technical success rate of $77 \%$, with primary patency at 3 months of $58 \%$, at 6 months of $45 \%$ and at 12 months of $29 \%$ (Table 2).

Moving on to stents, these were used for the first time by Gunther et al. in 1989, for treatment of refractory cases of COVD. ${ }^{21}$ They are considered a second line of treatment. Stents provide mechanical support for the stenosis site, when it is resistant to angioplasty. Additionally, they are potentially useful for stenoses with kinks, elastic stenoses, circumscript perforations or dissections after angioplasties; they also establish and maintain patency of chronic occlusions in central veins. However, there are significant limitations to the use of stents. After they have been implanted, stents may migrate,

Table 2. Primary and secondary patency of balloon angioplasty for central venous stenosis.

\begin{tabular}{|c|c|c|c|c|c|c|}
\hline Study & Year & $\begin{array}{c}\text { Number of par- } \\
\text { ticipants }\end{array}$ & $\begin{array}{c}\text { Primary success } \\
(\%)\end{array}$ & $\begin{array}{c}\text { Patency at } \\
3 \text { months (\%) }\end{array}$ & $\begin{array}{c}\text { Patency at } \\
6 \text { months (\%) }\end{array}$ & $\begin{array}{c}\text { Patency at } \\
12 \text { months (\%) }\end{array}$ \\
\hline Glanz et al. ${ }^{1}$ & 1988 & 29 & 76 & - & 50 & 35 \\
\hline Beathard ${ }^{15}$ & 1992 & 27 & 89 & 49 & 29 & - \\
\hline Kovalik et al. ${ }^{16}$ & 1994 & 30 & 70 & - & 43 & 13 \\
\hline Quinn et al. ${ }^{17}$ & 1995 & 24 & - & 100 & 23 & 12 \\
\hline Dammers et al. ${ }^{18}$ & 2003 & 20 & 90 & 63 & 50 & 50 \\
\hline Surowiec et al. ${ }^{19}$ & 2004 & 35 & 89 & - & 55 & 43 \\
\hline Bakken et al. ${ }^{20}$ & 2007 & 47 & 77 & 58 & 45 & 2 \\
\hline
\end{tabular}


shorten or fracture, and their use may impede future endovascular procedures or surgery. Furthermore, it is already evident that all stents can provoke intimal hyperplasia, leading to recurrent stenosis and multiple interventions to maintain patency. ${ }^{22}$ However, in common with balloon angioplasties, stents also demonstrate a wide range of variability in relation to patency after treatment of COVD. Patency can vary from 72 to $100 \%$ at 3 months, through 55 to $100 \%$ at 6 months to 56 to $97 \%$ at 12 months..$^{20,23-28}$ To our knowledge, to date there have been no prospective controlled studies comparing angioplasties with and without stents for treatment of COVD. In a retrospective study published by Bakken et al. in $2007^{20}$ and comparing angioplasties with and without stents, the authors showed that there were no significant differences in patency results between angioplasties with and without stents (Table 3).

Relating our results to those of others, we note that with relation to stenosis, a primary technical success rate of $100 \%$, followed by patency at 3 months of $93 \%$ and at 6 months of $80 \%$, is similar to what has been reported by other authors (Figure 4)..$^{1,15-20,23-28}$ Additionally, also in common with other authors, ${ }^{20,21}$ we did not observe superior patency in angioplasties with stents. Notwithstanding, our results differ with relation to obstructions, since we did not achieve technical success in any of theses cases. In 1999, Farrell et al. ${ }^{29}$ reported on five central venous obstruction recanalizations using the Rosch-Uchida needle, normally used to create intrahepatic shunts by puncture, without no major complications. Other authors have reported recanalization of obstructions using rigid guidewires. ${ }^{26}$ Notwithstanding, we have not had the opportunity to attempt these techniques and occlusions remain our greatest challenge in endovascular treatment of COVD. We consider these techniques to be aggressive and subject to complications with high morbidity and mortality.

Two points should be mentioned with relation to covered stents: the first is that it is imperative that they be available in the hemodynamics room if they are to be used to treat complications during angioplasty, as with the rupture that occurred in one of our own cases. The second point is that covered stents are also being used to treat lesions that are unresponsive to angioplasty, even using stents. ${ }^{26,30,31}$ The potential advantages of these materials include the provision of a relatively inert and stable intravascular matrix for endothelization, allied to the mechanical advantages offered by stents. This could reduce the intimal hyperplasia response, reducing restenosis rates after angioplasty. ${ }^{27} \mathrm{Kundu}^{32}$ published a study in which

Table 3. Primary and secondary patency of angioplasty for central venous stenosis with stents.

\begin{tabular}{|c|c|c|c|c|c|c|}
\hline Study & Year & $\begin{array}{c}\text { Number of par- } \\
\text { ticipants }\end{array}$ & $\begin{array}{c}\text { Primary success } \\
(\%)\end{array}$ & $\begin{array}{c}\text { Patency } \\
3 \text { months (\%) }\end{array}$ & $\begin{array}{c}\text { Patency } \\
6 \text { months (\%) }\end{array}$ & $\begin{array}{l}\text { Patency } 12 \\
\text { months (\%) }\end{array}$ \\
\hline Bakken et al. ${ }^{20}$ & 2007 & 26 & 96 & 72 & 55 & 46 \\
\hline Chen et al. ${ }^{23}$ & 2003 & 18 & 100 & 100 & 100 & 91 \\
\hline Vogel et al. ${ }^{24}$ & 2004 & 16 & 98 & 81 & 74 & 67 \\
\hline Aytekin et al. ${ }^{25}$ & 2004 & 14 & 100 & 100 & 89 & 56 \\
\hline Haage et al. ${ }^{26}$ & 1999 & 50 & 100 & 92 & 84 & 97 \\
\hline Vesely et al. ${ }^{27}$ & 1997 & 20 & 100 & 89 & 64 & 56 \\
\hline Gray et al. ${ }^{28}$ & 1995 & 52 & 96 & - & 76 & 33 \\
\hline
\end{tabular}

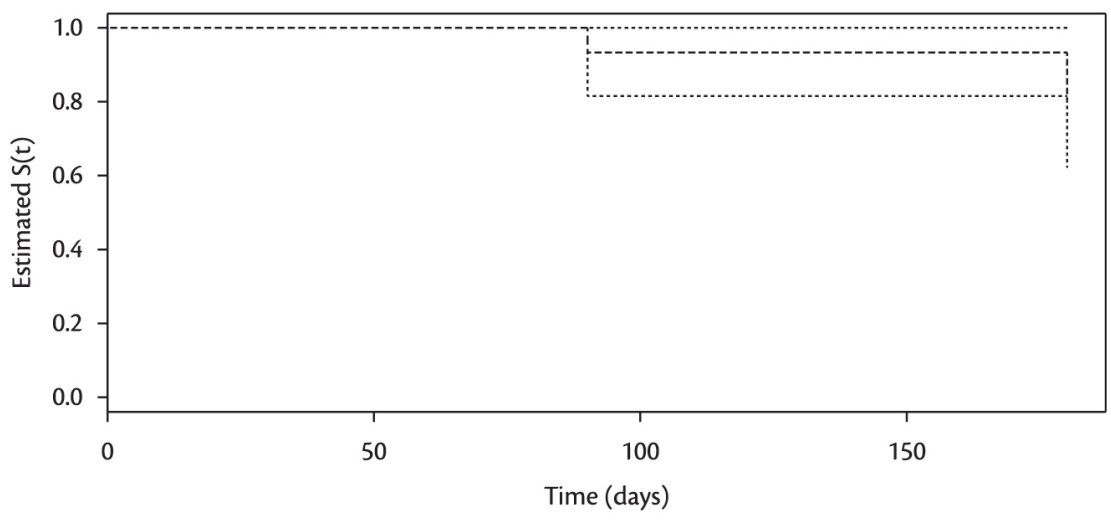

Figure 4. Kaplan-Meier curve: patency of central venous angioplasties. 
they employed eight covered stents for treatment of COVD, reporting primary patency at 3,6 and 9 months of $100 \%$. Notwithstanding, controlled and randomized clinical trials with longer follow-up periods are still needed.

\section{CONCLUSIONS}

Placement of central venous catheters or venous interventions are the most important risk factors for COVD. Despite the high rates of primary success obtained treating stenoses, the current options for treatment of this disease will, sooner or later, lead to restenosis or occlusion, requiring multiple interventions to maintain patency. This being the case, further controlled and randomized studies into the available treatment options are needed to develop adequate treatment algorithms. Further advances in techniques and new technologies and materials for treatment are also needed in order to achieve better results, including in venous occlusion cases, which are the greatest challenge to treat.

It is concluded that, in view of the great difficulty in achieving satisfactory results, prevention is paramount, including rational use of central venous access and appropriate planning of creation of arteriovenous fistulas in predialytic patients. As is the case with renal dysfunction, placement of central venous catheters should be avoided when possible and particularly so in the subclavian vein. Furthermore, use of other peripheral venous access routes should be minimized to preserve future venous access.

\section{REFERENCES}

1. Glanz S, Gordon DH, Lipkowitz GS, Butt KMH, Hong J, Sclafani SJA. Axillary and subclavian vein stenosis: percutaneous angioplasty. Radiology. 1988;168:371-3. PMid:2969117.

2. Agarwal AK, Patel BM, Farhan NJ. Central venous stenosis in hemodialy- sis patients is a common complication of ipsilateral central vein catheteriza- tion. J Am Soc Nephrol. 2004;15:368A-9A.

3. Vanherweghem JL, Yasine T, Goldman $M$, et al. Subclavian vein thrombosis: a frequent complication of subclavian cannulation for hemodialysis. Clin Nephrol. 1986;26:235-8. PMid:3802586.

4. Trerotola SO, Kuhn-Fulton J, Johnson MS, Shah H, Ambrosius WT, Kneebone $\mathrm{PH}$. Tunneled infusion catheters: increased incidence of symptomatic venous thrombosis in subclavian versus internal jugular venous access. Radiology. 2000;217:89-93. PMid:11012428. http://dx.doi.org/10.1148/radiology.217.1.r00oc2789

5. Palabrica T, Lobb R, Furie BC, et al. Leukocyte accumulation promoting fibrin deposition is mediated by P-selectin on adherent platelets. Nature. 1992;359:848-51. PMid:1279433. http://dx.doi. org/10.1038/359848a0

6. Weiss MF, Scivittaro V, Anderson JM. Oxidative stress and increased expression of growth factors in lesions of failed hemodialysis access. Am J Kidney Dis. 2001;37:970-80. http:// dx.doi.org/10.1016/S0272-6386(05)80013-7
7. Fillinger MF, Reinitz ER, Schwartz RA, et al. Graft geometry and venous intimal-medial hyperplasia in arteriovenous loop grafts. J Vasc Surg. 1990;11:556-66. http://dx.doi. org/10.1016/0741-5214(90)90302-Q

8. Neves Junior MAV, Petnys A, Melo RC, Babboni E. Acesso vascualr para hemodiálise: o que há de novo? J Vasc Bras. 2013;12(3):221-5.

9. Schwab SJ, Quarles LD, Middleton JP, Cohan RH, Saeed M, Dennis VW. Hemodialysis associated subclavian vein stenosis. Kidney Int. 1988;33:1156-9. PMid:2969991. http://dx.doi.org/10.1038/ ki.1988.124

10. Gadallah MF, El-Shahawy MA, Campese VM. Unilateral breast enlargement secondary to hemodilaysis arteriovenous fistula and subclavian vein occlusion. Nephron. 1993;63(3):351-3. PMid:8446276. http://dx.doi.org/10.1159/000187222

11. Wright RS, Quinones-Baldrich WJ, Anders AJ, Danovitch GM. Pleural effusion associated with ipsilateral breast and arm edema as a complication of subclavian vein catheterization and arteriovenous fistula formation for hemodialysis. Chest. 1994;106(3):950-2. PMid:8082387. http://dx.doi. org/10.1378/chest.106.3.950

12. Rose SC, Kinney TB, Bundens WP, Valji K, Roberts AC. Importance of Doppler analysis of transmitted atrial waveforms prior to placement of central venous cathe-ters. J Vasc Interv Radiol. 1998;9:927-4. http://dx.doi.org/10.1016/ S1051-0443(98)70424-5

13. Lumsden $A B$, MacDonald MJ, Isiklar $H$, et al. Central venous stenosis in the hemodialysis patient: incidence and efficacy of endovascular treatment. Cardiovasc Surg. 1997;5:504-9. http:// dx.doi.org/10.1016/S0967-2109(97)00043-4

14. Marckmann P, Skov L, Rossen K, et al. Nephrogenic systemic fibrosis: suspected causative role of gadodiamide used for contrast-enhanced magnetic resonance imaging. J Am Soc Nephrol. 2006;17:2359-62. PMid:16885403. http://dx.doi. org/10.1681/ASN.2006060601

15. Beathard GA. Percutaneous transvenous angioplasty in the treatment of vascular access stenosis. Kidney Int 1992;42:1390-7. PMid:1474770. http://dx.doi.org/10.1038/ki.1992.431

16. Kovalik EC, Newman GE, Suhocki P, Knelson M, Schwab SJ. Correction of central venous stenoses: use of angio- plasty and vascular Wallstents. Kidney Int. 1994;45:1177-81. PMid:8007589. http://dx.doi.org/10.1038/ki.1994.156

17. Quinn SF, Schuman ES, Demlow TA, et al. Percutaneous transluminal angioplasty versus endovascular stent placement in the treatment of venous stenoses in patients undergoing hemodialysis: intermediate results. J Vasc Interv Radiol. 1995;6:8515. http://dx.doi.org/10.1016/S1051-0443(95)71200-3

18. Dammers R, de Haan MW, Planken NR, van der Sande FM, Tordoir $\mathrm{JH}$. Central vein obstruction in hemodialysis patients: Results of radiological and surgical intervention. Eur J Vasc Endovasc Surg. 2003;26:317-21. PMid:14509897. http://dx.doi.org/10.1053/ ejvs.2002.1943

19. Surowiec SM, Fegley AJ, Tanski WJ, et al. Endovascular management of central venous stenoses in the hemodialysis patient: results of percutaneous therapy. Vasc Endovascular Surg. 2004;38:349-54. PMid:15306953. http://dx.doi.org/10.1177/153857440403800407

20. Bakken AM, Protack CD, Saad WE, Lee DE, Waldman DL, Davies MG. Long-term outcomes of primary angioplasty and primary stenting of central venous stenosis in hemodialysis patients. J Vasc Surg. 2007;45:776-83. PMid:17398386. http://dx.doi.org/10.1016/j. jvs.2006.12.046

21. Gunther RW, Vorwerk D, Bohndorf K, et al. Venous stenoses in dialysis shunts: treatment with self-expanding metallic stents. Radiology. 1989;170:401-5. PMid:2521397. 
22. Anaya-Ayala JE, Smolock CJ, Colvard BD. Efficacy of covered stent placement for central venous occlusive disease in hemodialysis patients. J Vasc Surg. 2011;54:754-9. PMid:21664095. http://dx.doi. org/10.1016/j.jvs.2011.03.260

23. Chen CY, Liang HL, Pan HB, et al. Metallic stenting for treatment of central venous obstruction in hemodialysis patients. J Chin Med Assoc. 2003;66:166-72. PMid:12779037.

24. Vogel PM, Parise CP. SMART stent for salvage of hemodialysis access grafts.J Vasc Interv Radiol. 2004;15:1051-60. PMid:15466790. http://dx.doi.org/10.1097/01.RVI.0000129915.48500.DC

25. Aytekin C, Boyvat F, Yağmurdur MC, Moray G, Haberal M. Endovascular stent placement in the treatment of upper extremity central venous obstruction in hemodialysis patients. Eur J Radiol. 2004;49:81-5. http://dx.doi.org/10.1016/ S0720-048X(02)00370-4

26. Haage P, Vorwerk D, Piroth W, Schuermann K, Guenther RW. Treatment of hemodialysis-related central venous stenosis or occlusion: results of primary wallstent placement and follow-up in 50 patients. Radiology. 1999;212:175-80. PMid:10405739. http:// dx.doi.org/10.1148/radiology.212.1.r99j|21175

27. Vesely TM, Hovsepian DM, Pilgram TK, Coyne DW, Shenoy S. Upper extremity central venous obstruction in hemodialysis patients: treatment with Wallstents. Radiology. 1997;204:343-8. PMid:9240518.

28. Gray RJ, Horton KM, Dolmatch BL, et al. Use of Wallstents for hemodialysis access-related venous stenoses and occlusions untreatable with balloon angioplasty. Radiology. 1995;195:47984. PMid:7724770

29. Farrell T, Lang EV, Barnhart W. Sharp recanalization of central venous occlusions. JVIR. 1999;10:149-54. http://dx.doi. org/10.1016/S1051-0443(99)70457-4

30. Quinn SF, Kim J, Sheley RC. Transluminally placed endovascular grafts for venous lesions in patients on hemodial-ysis. Cardiovasc Intervent Radiol. 2003;26:365-9.

31. Kundu S, Modabber M, You JM, Tam P, Nagai G, Ting R. Use of PTFE stent grafts for hemodialysis-related central venous occlusions: inter- mediate-term results. Cardiovasc Intervent Radiol. 2011;34:949-57.
32. Kundu S. Central venous disease in hemodialysis patients: prevalence, etiology and treatment. J Vasc Access. 2010;11:1-7. PMid:20119911.

Correspondence Fernando Barbosa Trevisan Av. São Paulo, 550/1608 - Centro CEP 86010-060 - Londrina (PR), Brazi E-mail:fernandotrvsn@hotmail.com

Author information

JMSS é Professor Associado da Disciplina de Angiologia e Cirurgia Vascular do Departamento de Clínica Cirúrgica da Universidade Estadual de Londrina (UEL)

FBT é Residente de Angiorradiologia e Cirurgia Endovascular do Hospital Universitário Regional do Norte do Paraná WES é Professor Adjunto da Disciplina de Angiologia e Cirurgia Vascular do Departamento de Clínica Cirúrgica da Universidade Estadual de Londrina (UEL)

DMF é Professor Adjunto da Disciplina de Angiologia e Cirurgia Vascular do Departamento de Clínica Cirúrgica da Universidade Estadual de Londrina (UEL)

EDR é Professor Auxiliar da Disciplina de Angiologia e Cirurgia Vascular do Departamento de Clínica Cirúrgica da Universidade Estadual de Londrina (UEL).

SVMD é Residente de Cirurgia Vascular do Hospital Universitário Regional do Norte do Paraná

HM é Residente de Cirurgia Vascular do Hospital Universitário Regional do Norte do Paraná

Author contributions Conception and design: JMSS, FBT Analysis and interpretation: JMSS, FBT, WES, DMF, EDR, SVMD, HM Data collection: JMSS, FBT, WES, DMF, EDR, SVMD, HM Writing the article: JMSS, FBT, WES Critical revision of the article: IMSS, FBT Final approval of the article*: JMSS, FBT, WES, DMF, EDR, SVMD, HM Statistical analysis: JMSS, FBT Overall responsibility: JMSS, FBT

* All authors have read and approved of the final version of the article submitted to I Vasc Bras. 